\title{
STUDY ON CHEMISTRY OF OXIDATIVE DESULFURIZATION PROCESS OF HIGH SULFUR STRAIGHT-RUN OIL FRACTION
}

\author{
Serhiy Pyshyev ${ }^{1} \bowtie$, Bohdan Korchak ${ }^{1}$, Denis Miroshnichenko ${ }^{2}$, \\ Bemgba Bevan Nyakuma ${ }^{3}$
}

https://doi.org/10.23939/chcht15.03.414

\begin{abstract}
In the article the chemistry of the noncatalytic oxidative desulfurization process of distillate oil fractions is analyzed. The study involves the characteristics of highsulfur straight-run diesel fraction of narrow composition (593-623 K) before and after oxidation by air at 453$493 \mathrm{~K}$ and a pressure of $3.0 \mathrm{MPa}$. The composition of sulfur compounds in the raw material fraction was determined. It is shown that straight-run fractions of raw materials may also contain sulfoxides, which are products of oxidation of organosulfur compounds and are formed during storage of petroleum products. On the basis of IR spectroscopic studies of raw materials, oxidized products and model mixtures, the transformation depth of fr. 593$623 \mathrm{~K}$ sulfur compounds, which are distributed in the form of sulfones and sulfoxides in solid and liquid oxidation products, and partially remain in the purified fuel, was analyzed in the above-mentioned process.
\end{abstract}

Keywords: sulfur, diesel fuel, oxidative desulfurization, sulfoxide, sulfone.

\section{Introduction}

Over the last years, the emissions of $\mathrm{SO}_{x}$ from combustion fuels have become a serious environmental problem. Hence, strict environmental policies have been implemented worldwide to limit the sulfur levels in fuels to $10 \mathrm{ppm}$ [1]. Diesel fuel (DF) is a major transportation fuel and a significant source of pollution. To prevent air pollution caused by exhaust gases the governments worldwide have ordered the removal of sulfur from transportation fuels. For example, since July 2006 the

\footnotetext{
${ }^{1}$ Lviv Polytechnic National University,

12 Bandera St., Lviv 79013, Ukraine

${ }^{2}$ National Technical University, Kharkiv Polytechnic Institute,

2 Kyrpychova St., Kharkiv 61002, Ukraine

${ }^{3}$ Research Initiative for Sustainable Energy Technologies,

Makurdi, Benue State, Nigeria

gajva@polynet.lviv.ua

C Pyshyev S., Korchak B., Miroshnichenko D., Bevan Nyakuma B., 2021
}

mandatory sulfur content in DF in the USA has been restricted to $15 \mathrm{ppm}$ [2].

In Europe, mandatory environmental regulations for several fuel properties were first introduced in 1998 [3] but last revised in 2009 [4]. According to this regulation, the sulfur content in "sulfur-free" fuels must not exceed 10 ppm. Since 2000-2010, all developed and many developing countries have required an average sulfur content of about $10 \mathrm{ppm}$ in transportation fuels according to regulations [1, 4-7]. In Ukraine, the permissible content of sulfur compounds has reduced significantly in recent years. According to the Ukrainian standards [8] a sulfur content of is permitted in DF products, whereas [9] permits 10,50 and $350 \mathrm{ppm}$, lastly [10] allows for 10 and $50 \mathrm{ppm}$.

The requirements for the environmental properties of jet fuels (JF) are less strict both in Ukraine and worldwide. Therefore, the contribution of aviation to environmental pollution is becoming increasingly noticeable because the sulfur content of JF is 0.1$0.4 \mathrm{wt} \%$ (or $1000-4000 \mathrm{ppm}$ ). For special types of JF, the sulfur content up to $1.0 \mathrm{wt} \%(10000 \mathrm{ppm})$ is allowed [11, 12]. However, this could affect flight safety, power consumption, and stability of JF during transport and storage. Furthermore, the major emissions of JF combustion products that occur at high altitudes could also pose further environmental challenges.

Hence, the purification or removal of sulfur compounds from fuels has been proposed in the literature. Currently, the main technology widely used for sulfur removal is hydrotreating (HDS). However, the process has numerous several disadvantages such as the removal of sulfur compounds, heteroatoms, and other substances. The HDS process results in the partial hydration of aromatics, which automatically reduces the number of substances capable of adsorbing on metal surfaces. Consequently, the lubricating properties of the fuels are weakened significantly. The thiophene compounds and other condensed sulfur compounds present in the feedstock are not hydrotreated due to the spatial difficulties that occur during the contact with catalysts during HDS. For economic reasons, hydrotreating cannot be organized for the small scale production of DF or JF, for example, the 
hydrotreating products of such low-tonnage processes as plastics and rubber recycling.

Hence, alternative technologies for the desulfurization of straight-run fractions have been investigated extensively in the past few decades. The most notable technologies include: extraction [13], selective adsorption [14], and oxidative desulfurization (ODS) [15]. Among these, ODS is considered as one of the most promising techniques for desulfurization and currently it receives the growing attention. The greatest advantage of ODS compared to the conventional HDS process is that it can be carried out in a liquid phase and mild conditions without the need for expensive hydrogen $[15,16]$. However, the current industrial processes for oxidation purification are aimed only at the extraction of sour sulfur or increasing the thermo-oxidative stability of JF after hydrotreating. Most ODS processes developed or improved over last 20 years seek to reduce the sulfur content in hydrotreated fuels to $10-15 \mathrm{ppm}$ or less. However, these processes, along with HDS, are relatively complex and require the use of expensive catalysts and oxidizers [15-25].

In this study, the oxidative desulfurization of straight-run kerosene and diesel fractions with high sulfur content is examined along with hydrogenates by air treatment without the use of expensive catalysts and strong oxidizers. Previously, the major process conditions (pressure, fractional feedstock composition along with the methods for sulfur oxidation and products separation) were investigated [26-28]. The findings demonstrated that oxidation could be accomplished in a liquid phase such as the presence of water. Hence, the authors established the effect of temperature and water-to-feedstock ratio [29], the prospects of obtaining commercial JF [28], and components of DF with good lubricating properties [30]. The proposed technology could also be used for the purification of petroleum fuels or regeneration of used mineral motor oils produced on a small scale, particularly when hydrotreating is uneconomic or technologically impossible. Lastly, the process could also be used for the after-treatment of hydrogenates and partial desulfurization of straight-run fractions to produce fuel components with improved lubricating properties [29, 31-33].

Therefore, this paper seeks to investigate the chemical oxidation of sulfur compounds during treatment with air under predetermined conditions. It is envisaged that the findings will present a comprehensive understanding of various oxidative (air) transformations that occur in straight-run fractions during storage.

\section{Experimental}

\subsection{Methods}

The oxidation experiments were performed at an enlarged laboratory plant (Fig. 1). The plant consists of a reactor block with air compression and purification systems; gaseous reaction products cooling and recovery systems with temperature, pressure, consumption control and measuring instruments. The main apparatus is a bubble reactor with a volume of $0.7 \mathrm{l}$; an operating pressure is $15 \mathrm{MPa}$; temperature is $623 \mathrm{~K}$. The vertical movement of the reaction mixture in the reactor is achieved using an installed cylindrical tube in the reactor vessel. When the mixer is in operation, the reaction mixture is circulated upwards through the inner space of the pipe and down into the space between the reactor vessel and the pipe.

The main factors recorded during the process were: temperature, pressure, and duration. The term "volumetric oxidant flow rate" (VOFR, $\mathrm{min}^{-1}$ ), which is numerically equal to the ratio of oxidant consumption $\left(\mathrm{m}^{3} / \mathrm{min}\right)$ to the feedstock volume $\left(\mathrm{m}^{3}\right)$, was used to describe the air : feedstock ratio, time and the contact area used. In the case of the feedstock oxidation with water, the water phase was separated and then analysed along with the oxidate phase according to the scheme shown in Fig. 2. Distillation was carried out by the Engler's method, whereas the adsorption was carried out based on a developed method using silica gel as an adsorbent. However, benzene was used for desorption of the refined fuel. The mixture of alcohol and benzene was applied for desorption of LCOP.

Perbenzoic acid (PBA) is sufficiently selective and completely oxidizes sulfuric organic compounds $[34,35]$. Therefore, the samples for IR spectroscopy were obtained by processing the PBA feedstock. The acid was added to the raw materials in a ratio of 10:1 followed by stirring as required for the oxidation of all the sulfur compounds of the raw materials into sulfones. The excess and the formed benzoic acid were subsequently washed from the oxidized fuel with water until there was no acid reaction in the distilled water. Furthermore, the oxidate was separated and analysed according to Fig. 2.

The composition of the process products and process raw materials were examined by IR spectroscopy. The IR spectra were recorded on the SPECORD M-80 device using various techniques. The solid phase spectra of the oxidate were taken in $\mathrm{KBr}$ pellet; a part of the spectra of liquid samples was taken between $\mathrm{KBr}$ plates (in this case, the thickness constant of the absorption layer was controlled by a "zero" absorption line). The rest of the spectra of the liquid samples were placed in $\mathrm{KBr}$ cuvettes with a thickness of 0.1 or $1 \mathrm{~mm}$ of the absorbent layer. The identification of the IR spectra was performed according to the literature [36-40]. The feedstock and products were then analysed using standard methods.

\subsection{Materials}

The straight-run fraction was withdrawn at JSC "Naftokhimik Prykarpattya" (Ukraine). To increase the concentration of sulfur compounds in the initial diesel, a residual fraction $(553-623 \mathrm{~K})$ was distilled from it. The characteristics of the initial diesel fraction are presented in Table 1. 




Fig. 1. Scheme of laboratory installation of oxidative desulfurization of petroleum fractions: 1 - reactor, 2 - refrigerator, 3 - electric motor, 4 - seals, 5 - thermocouple, 6 - pipe, 7 - rotameter, 8,9 - receiver, 10 - compressor, 11 - manometers, 12 - valves, 13 - transformer, 14 - electric heater, 15 - cylinder with nitrogen, 16 - cylinder for gas collection



Fig. 2. Scheme of oxidate division and investigation

Table 1

Characteristics of the initial diesel fraction

\begin{tabular}{|l|c|}
\hline \multicolumn{1}{|c|}{ Index } & Values \\
\hline Density at $293 \mathrm{~K}, \mathrm{~kg} / \mathrm{m}^{3}$ & 856 \\
\hline Content of total sulfur, wt \% (ppm) & $0.869(8690)$ \\
\hline Concentration of actual gums, $\mathrm{mg} / 100 \mathrm{~cm}^{3}$ & 15.0 \\
\hline Acidity, $\mathrm{mg} \mathrm{KOH} / 100 \mathrm{~cm}^{3}$ & 5.9 \\
\hline Content of individual sulfur groups in total sulphur, wt \%: & 0.92 \\
- sour & 58.85 \\
- sulfide aliphatic & 40.23 \\
- residual (cyclic sulfides and thiophenes) & \\
\hline
\end{tabular}




\section{Results and Discussion}

In this study, IR spectroscopy was used to examine the mechanism and completeness of the oxidation of the sulfur compounds contained in the selected raw material. Hence, the following samples were prepared:

- Oxidized fr. 553-623 K using the method investigated in the work. The liquid oxide phase (OLP) was separated by adsorption according to the scheme shown in Fig. 2 (adsorbent is a silica gel);

- Oxidized fr. 553-623 K using perbenzoic acid (PBA);

- Prepared model mixtures containing sulfones or sulfoxides.

Given the multidimensionality of the mixtures under study and the resulting complexity of IR spectroscopy, the focus was on the presence or absence of the sulfoxide ( $\mathrm{SO}$ ) and sulfone $\left(\mathrm{SO}_{2}\right)$ groups. The list of samples used in this series of IR spectroscopic studies is given in Tables 2 and 3. The spectra are shown in Figs. 3-13.

The oscillation frequencies of the $\mathrm{SO}$ and $\mathrm{SO}_{2}$ groups depend on the composition of the hydrocarbon radical, the phase state, and the environment in which the sulfones and sulfoxides reside. Sulfoxides are characterized by bands in the regions of $1070-1030 \mathrm{~cm}^{-1}[39,40]$. In the analysis of solids, the absorption frequency is reduced by $10-20 \mathrm{~cm}^{-1}[36,39,40]$. Sulfones are characterized by bands in the regions of $1358-1300$ and $1120-1169 \mathrm{~cm}^{-1}$ $[36,39,40]$. The oscillation intervals of other sulfur-oxygen compounds are even wider [38-41]. The analysis of the presence of sulfone groups and sulfoxide groups is also complicated by the fact that in the above areas fluctuations may occur in the substances containing other groups and, theoretically, may be formed during the oxidative desulphurization process. For example, primary alcohols may give characteristic bands on the IR spectrogram at 1075-1000 and 1350-1260 $\mathrm{cm}^{-1}$, secondary alcohols occur at $1125-1030 \mathrm{~cm}^{-1}$, and peroxides - at $1150 \mathrm{~cm}^{-1}[40,41]$. Therefore, the confirmation of the sulfones and sulfoxides formation during the process is the presence of the raw peaks characteristic of sulfur compounds on the spectrogram. Typically, the absence (reduction) of these peaks in the oxidized product with the simultaneous appearance of peaks is inherent in sulfones and sulfoxides. The spectra shown in Figs. 3-6 determine the presence of sulfone and sulfoxide groups in the feedstock and products of the process. The analysis was performed in the $\mathrm{KBr}$ cells with the thickness of $0.1 \mathrm{~mm}$.

Table 2

\section{Characteristics of the samples}

\begin{tabular}{|l|c|c|}
\hline \multicolumn{1}{|c|}{ Sample } & Method and conditions for obtaining the sample & Figure number \\
\hline Oxidate solid phase (OSP) & $453 \mathrm{~K} ; 30 \mathrm{~min}$; VOFR $=1.65 \mathrm{~min}^{-1} ; 3.0 \mathrm{MPa}$ & 3 \\
\hline Refined fuel (RF) & $453 \mathrm{~K} ; 30 \mathrm{~min}$; VOFR $=1.65 \mathrm{~min}^{-1} ; 3.0 \mathrm{MPa}$ & 4 \\
\hline Oxidate liquid phase (OLP) & $453 \mathrm{~K} ; 30 \mathrm{~min}$; VOFR $=1.65 \mathrm{~min}^{-1} ; 3.0 \mathrm{MPa}$ & 5 \\
\hline Fr. 553-623 K & - & 7 \\
\hline Oxidate liquid phase (OLP) & Oxidation with perbenzoic acid (PBA) & 8 \\
\hline Fr. 553-623 K & - & 9 \\
\hline Oxidate liquid phase (OLP) & $493 \mathrm{~K} ; 30 \mathrm{~min}$; VOFR $=1.65 \mathrm{~min}^{-1} ; 3.0 \mathrm{MPa}$ & 10 \\
\hline Benzene+OLP $(1: 1, \mathrm{w} / \mathrm{w})$ & $453 \mathrm{~K} ; 30 \mathrm{~min}$; VOFR $=1.65 \mathrm{~min}^{-1} ; 3.0 \mathrm{MPa}$ & \\
\hline
\end{tabular}

Table 3

Characteristics of model mixtures

\begin{tabular}{|c|c|c|c|}
\hline Sample & $\begin{array}{c}\text { Content of sulfone group, wt } \\
\%\end{array}$ & $\begin{array}{c}\text { Content of sulfoxide group, wt } \\
\%\end{array}$ & Figure number \\
\hline Fr. 553-623 K+ sulfoxide & - & 1.43 & 11 (a) \\
\hline Fr. 553-623 K+ sulfoxide & - & 2.43 & 11 (b) \\
\hline Benzene $+280-350^{\circ} \mathrm{C} \mathrm{fr}(1: 1 \mathrm{wt} \%)+$ sulfone $^{2}$ & 0.35 & - & 12 \\
\hline Benzene $+280-350^{\circ} \mathrm{C} \mathrm{fr}(1: 1 \mathrm{wt} \%)+$ sulfoxide $^{1}$ & - & 2.37 & 13 \\
\hline
\end{tabular}

Notes: ${ }^{1}$ dimethyl sulfoxide (DMSO); ${ }^{2}$ 4,4'-dichlorodiphenyl sulfone (DCDPS)

Analysis of the OSP spectrum (see the spectrum in Fig. 3) shows the presence of two peaks in the region of $1335-1315 \mathrm{~cm}^{-1}$ and two peaks at $1155-1130 \mathrm{~cm}^{-1}$, which can be attributed to sulfone groups. However, there are no bands in the absorption region characteristic of sulfoxides
(1060-1030 $\mathrm{cm}^{-1}$ ). The refined fuel (see the spectrum in Fig. 4) also contains sulfones with bands at $1300 \mathrm{~cm}^{-1}$ and about $1350 \mathrm{~cm}^{-1}$ (as the "peak" peak at $1376 \mathrm{~cm}^{-1}$ ) and bands in the interval of $1170-1145 \mathrm{~cm}^{-1}$. Furthermore, the peaks at $1030 \mathrm{~cm}^{-1}$ may be due to sulfoxides. The 
spectrum of the liquid phase of the oxidate (spectrum in Fig. 5) is also analysed. The study showed that they contain more clearly (compared to IR refined fuel) bands characteristic of sulfones (1324 - peak shoulder at 1376, 1300,1168 and $\left.1150 \mathrm{~cm}^{-1}\right)$ and sulfoxides $\left(1032 \mathrm{~cm}^{-1}\right)$. In the spectrum in Fig. 6 (raw material is fr. 553-623 K FR), although there is a peak at $1168 \mathrm{~cm}^{-1}$, there are practically no peaks in the range of $1360-1300 \mathrm{~cm}^{-1}$, which indicates the absence of sulfonic groups. At $1030 \mathrm{~cm}^{-1}$ there is a slight absorption intensity, i.e. a small number of sulfoxides may be present in the raw material.

An approximate analysis of the oxidation depth of sulfur compounds during the process was carried out by comparing the IR spectra of the liquid phase of the oxide obtained by oxidation using extra-benzoic acid (PBA)

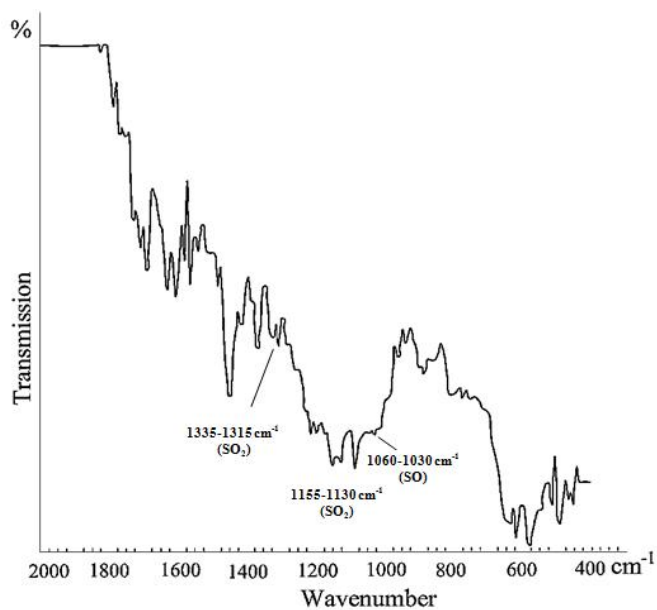

Fig. 3. IR spectrum of OSP

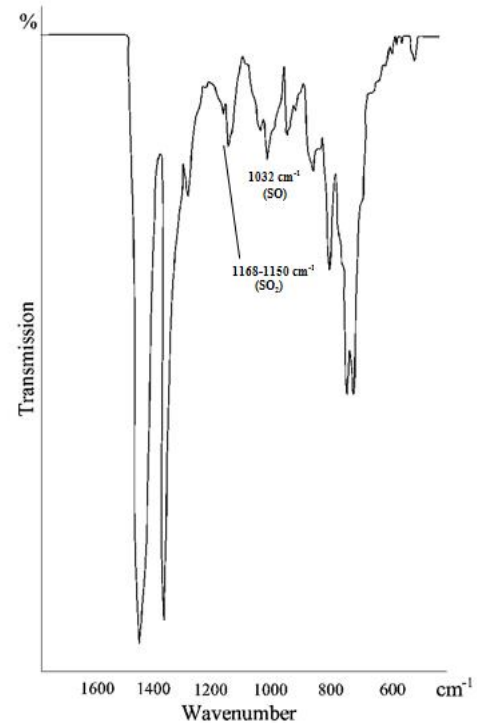

Fig. 5. IR spectrum of OLP
(Fig. 7), the raw material (Fig. 8), and the OLP obtained in the process (Fig. 9). According to [38] and [39], PBA can sufficiently, selectively and completely oxidize all sulfur compounds. When identifying the bands of spectrum 8 (fr. 553-623 K), the peaks determined in the ranges of $2920-2856,1460,1376,744,720 \mathrm{~cm}^{-1}$, are caused by the valence and deformation vibrations of the $\mathrm{CH}_{2}$ and $\mathrm{CH}_{3}$ groups characteristic of $n$ - and iso-alkane and cyclan compounds, respectively; 1604, 1450 and about $800 \mathrm{~cm}^{-1}$ (aromatic fragments); and $720-68 \mathrm{~cm}^{-1}$ for sulfides; $\sim 2650 \mathrm{~cm}^{-1}$ for $\mathrm{S}-\mathrm{CH}_{2}-$ groups; and $1225 \mathrm{~cm}^{-1}$ for thiophene. Based on the above, it can be argued that virtually all sulfur in the raw material is represented by sulfide and thiophene structures, which coincide with the data in Table 1.

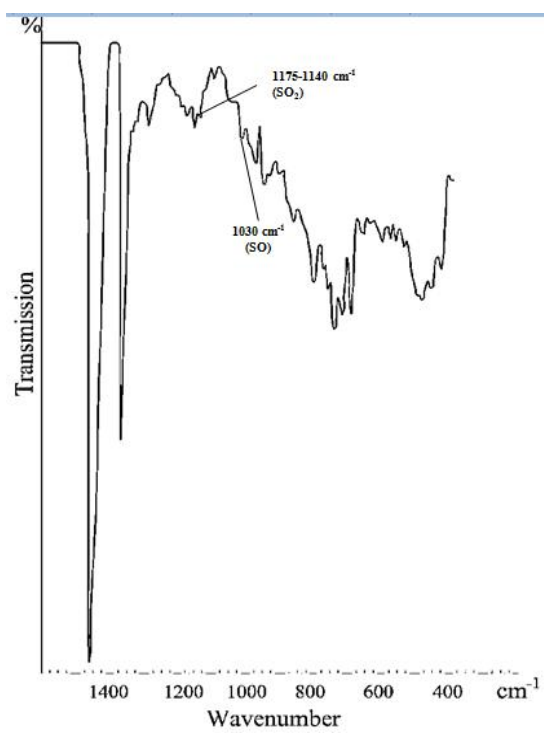

Fig. 4. IR spectrum of RF

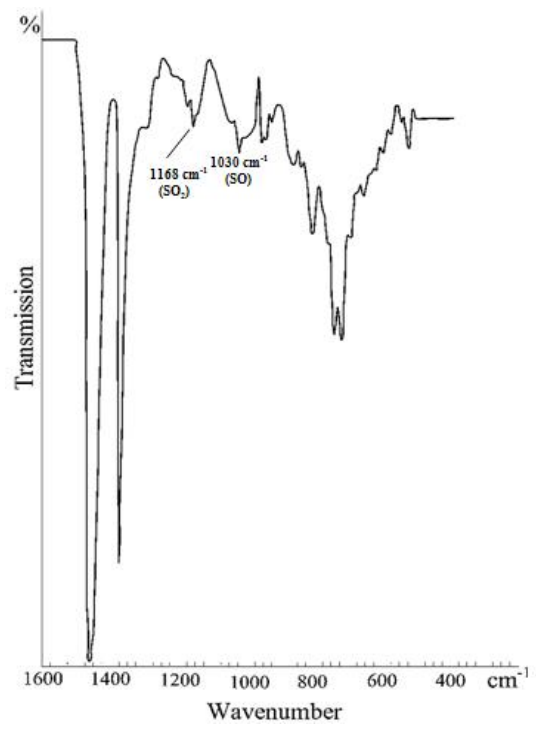

Fig. 6. IR spectrum of fr. 553-623 K 
The spectral analyses of the liquid oxidate phase from oxidation using extra-benzoic acid (spectrum in Fig. 7) showed that, in addition to the above absorption bands of alkane, cycloalkane and arene hydrocarbons, new absorption bands appeared at 3200, 1704 and $1575 \mathrm{~cm}^{-1}$. The peaks at 3200 and $1704 \mathrm{~cm}^{-1}$ indicate an increase (compared to the raw material) of the number of acids in the products. The peak at $3200 \mathrm{~cm}^{-1}$ may also indicate the presence of alcohol groups; whereas the band at $1575 \mathrm{~cm}^{-1}$ denotes the formation of salts of carboxylic acids during the process. In the PBA oxidized sample, the bands disappear or become much smaller, which is characteristic of the organo-sulfur compounds present in the raw materials $\left(720-680,1225\right.$ and $\left.2650 \mathrm{~cm}^{-1}\right)$. However, there are bands with a maximum at $1328 \mathrm{~cm}^{-1}$ (peak shoulder at $1304 \mathrm{~cm}^{-1}$ ), 1160 and $1060 \mathrm{~cm}^{-1}$. These can be interpreted as the valence asymmetric oscillation of the $\mathrm{SO}_{2}$ group



Fig. 7. IR spectrum of OLP obtained by oxidation with PBA

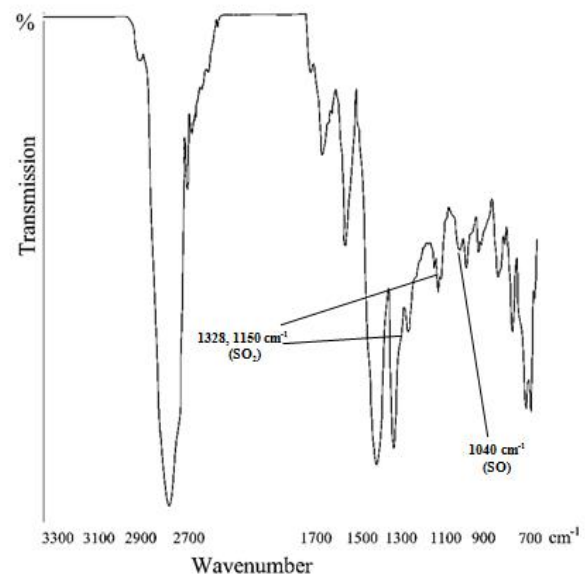

Fig. 9. IR spectrum of OLP $\left(1328 \mathrm{~cm}^{-1}\right)$ or the valence symmetric oscillation of the $\mathrm{SO}_{2}$ group $\left(1160 \mathrm{~cm}^{-1}\right)$ and the valence oscillation of the sulfoxide groups $\left(1060 \mathrm{~cm}^{-1}\right)$. The data of the spectrum of raw materials oxidized by the investigated method (spectrum in Fig. 9) are almost similar to the results obtained in the analysis of the spectrum in Fig. 7, except when the peaks corresponding to the organic acids are slightly larger. Therefore, in subsequent studies, the approximate concentrations of sulfones and sulfoxides were determined by comparing the IR spectra of the model mixtures with the known content of $\mathrm{SO}_{2}$ and $\mathrm{SO}$ groups with the OLP IR spectra obtained during the oxidative desulfurization process. The absorption band intensity was taken as an area of the peak calculated by the trapezoid method [42]. Dimethyl sulfoxide (DMSO) and 4,4'-dichlorodiphenyl sulfone (DCDPS) were used to create the model mixtures.

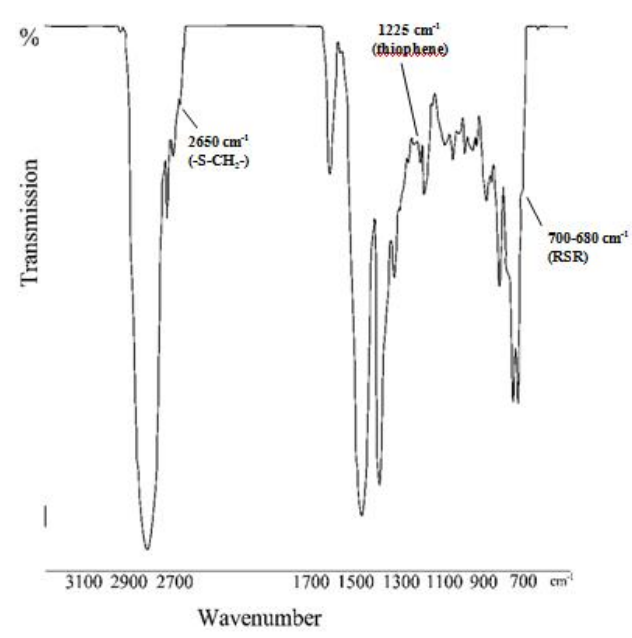

Fig. 8. IR spectrum of fr. 553-623 K

The spectra shown in Figs. 10-13 were obtained using cells with a width of $0.1 \mathrm{~mm}$. The initial medium without sulfones and sulfoxides was used for comparison. This approach helped to accurately distinguish the absorption bands of sulfones and sulfoxides. The IR spectrograms for the fr. 553-623 K with DMSO concentrations correspond to the quantities of SO groups of 1.43 and $2.43 \mathrm{wt} \%$. The spectra in Fig. 11 show that the intensity of the SO peaks is almost independent of the amount of DMSO in these mixtures. This occurrence is explained by the relatively poor solubility of sulfones and sulfoxides with a short hydrocarbon radical in hydrocarbons, i.e., when added to straight-run petroleum fractions of DCDPS in quantities corresponding to the content of the mixture of sulfone group at the level of $0.5-1.0 \mathrm{wt} \%$. The limited solubility of DCDPS in the petroleum fractions could be observed clearly. 
Therefore, benzene was used to dissolve the sulfoxides and sulfones in a mixture with petroleum products $(1: 1, \mathrm{w} / \mathrm{w})$. The analysis of several IR spectra of the raw material and benzene mixtures with DCDPS and DMSO applications showed that the peak intensity of sulfones and sulfoxides was almost directly proportional to their amount in the solution (relative error $<7 \%$ ). In Fig. 12, the $\mathrm{SO}_{2}$ exhibits clear absorption bands at 1160 and $1336 \mathrm{~cm}^{-1}$, whereas in Fig. 13 the SO group appears at $1072 \mathrm{~cm}^{-1}$. The peak area of sulfoxide in Fig. 13 is much larger than the area of a similar peak in Fig. 11b, indicating the dissolution of DMSO in the presence of benzene.

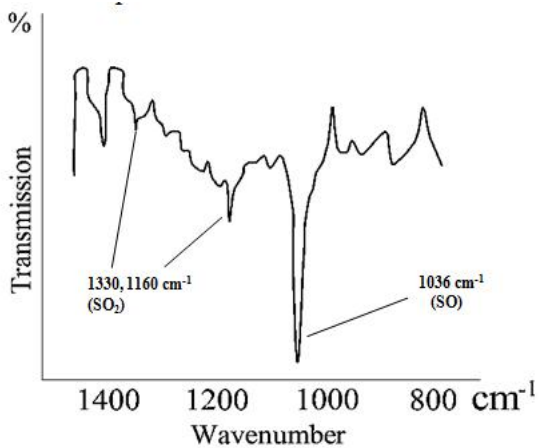

Fig. 10. IR spectrum of benzene + OLP $(1: 1, w / w)$



Fig. 12. IR spectrum of benzene + fr. 553$623 \mathrm{~K}(1: 1, \mathrm{w} / \mathrm{w})+$ sulfone; content of sulfone groups is $0.35 \mathrm{wt} \%$

The spectra in Figs. 12 and 13 were compared with the IR spectrum of the liquid phase of the oxidate obtained by oxidation of fr. $553-623 \mathrm{~K}$ in a mixture with benzene (Fig. 10). The investigated OLP contained $0.84 \%$ of the mass of sulfur. The spectral analysis of Fig. 10 shows that there are peaks at 1330 and $1160 \mathrm{~cm}^{-1}$ in the regions, which are characteristic of sulfone groups and a peak at $1036 \mathrm{~cm}^{-1}$ for the sulfoxide group. The calculation of the number of sulfone and sulfoxide groups in sample 10 based on the model spectra (Figs. 12 and 13) proves
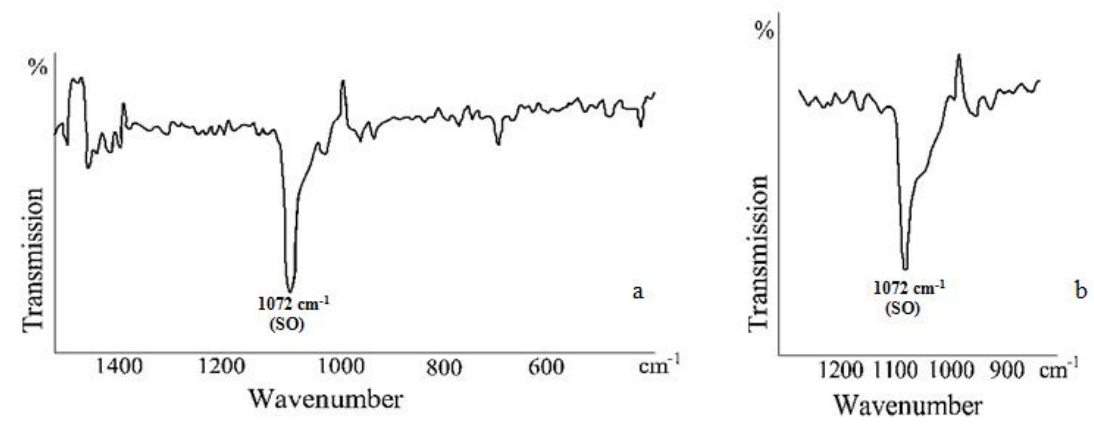

Fig. 11. IR spectrum of fr. 553-623 K + sulfoxide; content of sulfoxide groups is $1.43 \mathrm{wt} \%$ (a) and $2.43 \mathrm{wt} \%$ (b)



Fig. 13. IR spectrum of benzene + fr. 553-623 K (1:1, w/w) + + sulfoxide; content of sulfoxide groups is $2.37 \mathrm{wt} \%$

that the content of sulfone groups in the liquid phase of the oxide is about $0.36 \mathrm{wt} \%$ (in terms of sulfur it is $0.18 \mathrm{wt} \%$ ), sulfoxide - about $0.95 \mathrm{wt} \%$ (in terms of sulfur it is $0.63 \mathrm{wt} \%$ ).

The test product contains $0.84 \mathrm{wt} \%$ of sulfur, being about $0.81 \mathrm{wt} \%$ of this sulfur ( $96.4 \%$ relative) in an oxidized form. This suggests that all sulfur compounds under the process conditions (presented in Table 2) are oxidized by the following possible equations, some of which are given below [37, 43, 44]: 




\section{Conclusions}

The study examined the chemistry of the oxidative desulfurization of high sulfur straight-run oil fraction. In the raw materials (fr. 553-623 K), the oxidation products of sulfur compounds are not contained or contained in small quantities. The small amounts of sulfur oxidation products contained in fr. 553-623 K may be sulfoxides formed during the storage of raw materials. In the solid oxidation products (OSPs) creation, deeper oxidation products sulfones are involved, while the refined fuels and OLPs may also contain sulfoxides. After the high pressure and temperature oxidation, the sample contains approximately the same amount of sulfones and sulfoxides as the sample obtained by oxidation with extra-benzoic acid, which oxidizes all sulfur compounds. During the study, over $96 \mathrm{wt} \%$ of the sulfur compounds were oxidized, that is mainly all types of organo-sulfur compounds since the amount of thiophene and cyclic sulfide sulfur in the feedstock is $40.23 \%$ of the total sulfur.

\section{References}

[1] Ismagilov Z., Yashnik S., Kerzhentsev M. et al.: Cat. Rev. Sci. Eng., 2011, 53, 199. https://doi.org/10.1080/01614940.2011.596426 [2] U.S.EPA Regulatory Impact Analysis: Heavy-Duty Engine and Vehicle Standards and Highway Diesel Fuel Sulfur Control Requirements. EPA 420-R-00-026. December 2000.

[3] Directive 98/70/EC of the European Parliament and of the Council of 13 October 1998 relating to the quality of petrol and diesel fuels and amending Council Directive 93/12/EEC.

[4] Directive 2009/30/EC of the European Parliament and of the Council of $23^{\text {rd }}$ April 2009 amending Directive 98/70/EC as regards the specification of petrol, diesel and gas-oil and introducing a mechanism to monitor and reduce greenhouse gas emissions and amending Council Directive 1999/32/EC as regards the specification of fuel used by inland waterway vessels and repealing Directive 93/12/EEC.

[5] EN 590:2009. Automotive fuels. Diesel. Requirements and test methods.

[6] https://www.epa.gov/sites/production/files/2015-

08/documents/peg.pdf

[7] https://www.oica.net/wp-content/uploads/2007/06/wwfc-fourthedition-sep-2006.pdf
[8] DSTU 8705:2017. Diesel fuel for long-term storage. Specification. [9] DSTU 7688:2015. Diesel fuel EURO. Specification.

[10] DSTU 4840:2007. Diesel fuel of improved quality. Specification.

[11] Link D., Baltrus J., Rothenberger K. et al.: Energy Fuels, 2003, 17, 1292. https://doi.org/10.1021/ef0300747

[12] http://arge.stanford.edu/courses/2017/ph240/chhoa1/docs/exxon2008.pdf

[13] Huaming L., Lining H., Jidong L. et al.: Energy Fuels, 2009, 23,

1354. https://doi.org/10.1021/ef800797n

[14] van Rheinberg O., Klaus L., Heinrich K. et al.: Fuel, 2008, 87,

2988. https://doi.org/10.1016/j.fuel.2008.03.020

[15] Babich I., Moulijn J.: Fuel, 2003, 82, 607.

https://doi.org/10.1016/S0016-2361(02)00324-1

[16] Banisharif F., Dehghani M., Capel-Sánchez M., Campos-Martin J.: Ind. Eng. Chem. Res., 2017, 56, 3839.

https://doi.org/10.1021/acs.iecr.7b00089

「17] Chen L.-J., Li F.-T.: Pet. Sci. Technol., 2015, 33, 196.

https://doi.org/10.1080/10916466.2014.974817

[18] Julião D., Mirante F. et al.: Fuel, 2019, 241, 616.

https://doi.org/10.1016/j.fuel.2018.11.095

[19] Liu W., Li T., Yu G. et al.: Fuel, 2020, 265, 116967.

https://doi.org/10.1016/j.fuel.2019.116967

[20] Mirante F., Alves A. et al.: Fuel, 2020, 259, 116213.

https://doi.org/10.1016/i.fuel.2019.116213

[21] Jatav S., Srivastava V.: Pet. Sci. Technol., 2019, 37, 633.

https://doi.org/10.1080/10916466.2018.1560323

¡22] Wan Mokhtar W., Wan Azelee Wan Abu Bakar et al.: Pet. Sci.

Technol., 2018, 36:21, 1741 .

https://doi.org/10.1080/10916466.2018.1511581

[23] Wang B., Dai B., Kang L., Zhu M.: Fuel, 2020, 265, 117029.

https://doi.org/10.1016/i.fuel.2020.117029

$\lceil 24\rceil$ Tang X.-D., Wang C., Li J.-J. et al.: Pet. Sci. Technol., 2020, 38,

723. https://doi.org/10.1080/10916466.2020.1771365

$\lceil 25\rceil$ Zhao D., H. Ren, Y. Zhao \& J. Jia.: Petroleum Science and

Technology, 2009, 27:12, 1338.

https://doi.org/10.1080/10916460802105682

[26] Pysh'yev S., Bratychak M., Lazorko O., Shyshchak O.: Pol. J.

Environ. Stud., 2005, 14, 123.

[27] Pysh'yev S., Lazorko O., Bratychak M.: Chem. Chem. Technol., 2009, 3, 77.

[28] Lazorko O., Pysh'yev S., Bratychak M.: Chem. Chem. Technol., 2008, 2, 309.

[29] Pysh'yev S., Lazorko O., Bratychak M.: Chem. Chem. Technol., 2009, 3, 163.

[30] Paniv P., Pysh'yev S., Haivanovych V., Lazorko O.: Chem. Tech. Fuels Oils, 2006, 3, 7.

[31] Pysh'yev S.: Chem. Chem. Technol., 2012, 6, 229.

https://doi.org/10.23939/chcht06.02.229

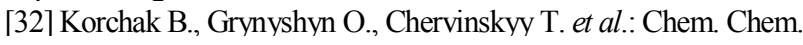

Technol., 2020, 14, 129. https://doi.org/10.23939/chcht14.01.129 
[33] Pysh'yev S., Bratychak M.: Chem. Chem. Technol., 2020, 14, 403. https://doi.org/10.23939/chcht14.03.403

[34] Oae S.: Organic Chemistry of Sulfur. Springer 1977. https://doi.org/10.1007/978-1-4684-2049-4

[35] Collins F., Lucy A., Sharp Ch.: J. Mol. Catal. A., 1997, 117, 397. https://doi.org/10.1016/S1381-1169(96)00251-8

[36] Nakanishi K.: Infrared Absorption Spectroscopy - Practical. Holden-Day, Inc., San Francisco 1964.

[37] Bolshakov G.: Sulfur Reports, 1986, 5, 103.

https://doi.org/10.1080/01961772.1986.10878150

[38] Bolshakov G.: Infrakrasnye Spectry Arenov. Monograph. Nauka, Novosibirsk 1989.

[39] Bellamy L.: The Infra-Red Spectra of Complex Molecules. Springer, Netherlands 1975. https://doi.org/10.1007/978-94-011-6017-9 [40] Kazitsina L., Kupletskaya N.: Primenenie UF-, IK-, YMR-i Massspektroskopii v Organicheskoi Khimii. Khimia, Moskva 1997.

[41] Bolshakov G., Glebovskaya E., Kaplan Z.: Spektry i Radiogrammy Heteroorganicheskykh Soedinenii. Khimia, Leningrad 1967.

[42] Wartewig S.: IR and Raman Spectroscopy Fundamental Processing. Wiley-VCH Verlag GmbH, Weinheim 2003.

https://doi.org/10.1002/3527601635

[43] Karaulova E.: Khimia Neftianykh Sulfidov. Nauka, Moskva 1970. [44] Odinokov V., Kukovinets O., Ishmuratov G. et al.: Neftekhimia, 1979, 19, 103.

Received: December 01, 2020 / Revised: December 12, 2020 / Accepted: December 22, 2020

\section{ВИВЧЕННЯ ХІМІЗМУ ПРОЦЕСУ ОКСИДАЦІЙНОЇ ДЕСУЛЬФУРИЗАЦЇ ВИСОКОСІРЧИСТОЇ ПРЯМОГОННОЇ НАФТОВОЇ ФРАКЩЇ}

Анотація. Проаналізовано хімізм проиесу некаталітичного оксидаційного знесірчення дистилятних нафтових фракиій. Проведено дослідження характеристик високосірчистої прямогонної дизельного фракиії вузького складу (593623 К) до і після окиснення повітрям за 453-493 К та тиску 3,0 МПа. Визначено груповий склад сірчистих сполук у фракиіі вихідної сировини. Показано, щзо прямогонні фракції вихідної сировини можуть також містити сульфоксиди, які є продуктами окиснення сірчаноорганічних сполук і утворюються при зберіганні нафтопродуктів. На основі ІЧ-спектроскопічних досліджень вихідної сировини, окиснених продуктів та модельних сумішей проаналізовано глибину перетворення $у$ вищезгаданому прочесі сірчистих сполук фр. 593-623 K, які розподіляються у вигляді сульфонів та сульфоксидів у твердих $i$ рідких продуктах окиснення ц̌ частково залишаються 6 очищеному паливі.

Ключові слова: сірка, дизельне паливо, оксидачійна десульфуризачія, сульфоксид, сульфон. 